\title{
Guidelines for Identification and Management of Plant Disease Problems: Part II. Diagnosing Plant Diseases Caused by Fungi, Bacteria and Viruses ${ }^{1}$
}

\author{
Ken Pernezny, Monica Elliott, Aaron Palmateer and Nikol Havranek ${ }^{2}$
}

\section{Introduction}

In the preceding section on identifying plant health problems (http://edis.ifas.ufl.edu/MG441), we explained how to first identify problems related to environmental factors or caused by insects. In this section, we will concentrate on diagnosing plant diseases caused by pathogenic microorganisms, primarily fungi, bacteria, and viruses. Nematodes are microscopic "worms" that can also cause plant health problems. They are discussed separately at http://edis.ifas.ufl.edu/NG006.

The study of pathogens and the diseases they cause is the traditional concern of plant pathologists. The specialized training and techniques needed to work with these microorganisms require most plant pathologists to limit their endeavors to pathogen-related problems.

\section{Types of pathogens}

To diagnose plant diseases effectively, it is necessary to understand the biology of the microorganisms that cause them: fungi, bacteria, and viruses.

\section{Fungi}

About $85 \%$ of plant diseases are caused by fungi: multi-celled microorganisms which may be seen without a microscope during certain stages of their life cycles. Fungi have no chlorophyll and their cell walls are composed of chitin and other polysaccharides instead of cellulose, which composes plant cell walls. Many species of fungi can be identified by the microscopic spores they produce reproductive structures that aid in dispersal and survival (Figs. 1 and 2). Some fungi have no spores, such as Rhizoctonia, which can be identified microscopically by the very characteristic right angle branches of its fungal threads (Fig. 3).

1. This document is PP249, one of a series of the Plant Pathology Department, Florida Cooperative Extension Service, Institute of Food and Agricultural Sciences, University of Florida. Original publication date February 2008. Visit the EDIS Web Site at http://edis.ifas.ufl.edu.

2. Ken Pernezny, professor, Department of Plant Pathology, Everglades Research and Education Center (REC)--Belle Glade, FL; Monica Elliott, professor, Department of Plant Pathology; Fort Lauderdale REC--Ft. Lauderdale, FL; Aaron Palmateer, assistant professor, Plant Diagnostic Clinic, Tropical REC--Homestead, FL; Nikol Havranek, biological scientist, Everglades REC--Belle Glade, FL; Florida Cooperative Extension Service, Institute of Food and Agricultural Sciences, University of Florida, Gainesville FL 32611.

The Institute of Food and Agricultural Sciences (IFAS) is an Equal Opportunity Institution authorized to provide research, educational information and other services only to individuals and institutions that function with non-discrimination with respect to race, creed, color, religion, age, disability, sex, sexual orientation, marital status, national origin, political opinions or affiliations. U.S. Department of Agriculture, Cooperative Extension Service, University of Florida, IFAS, Florida A. \& M. University Cooperative Extension Program, and Boards of County Commissioners Cooperating. Larry Arrington, Dean 


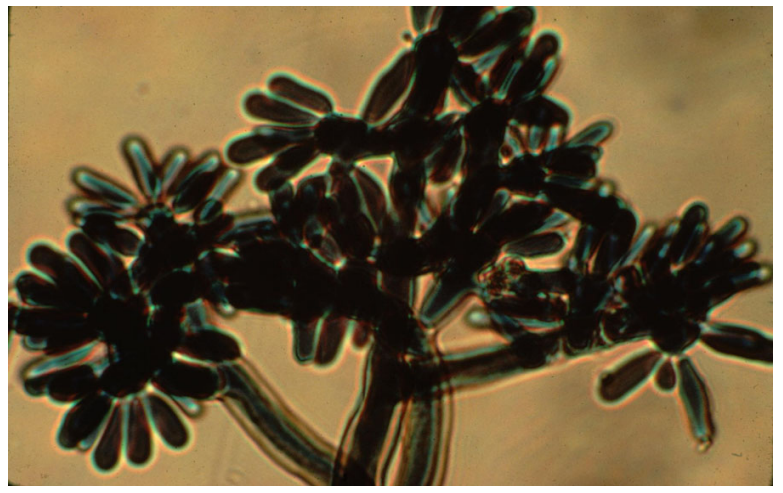

Figure 1. Botrytis spores seen under the microscope.

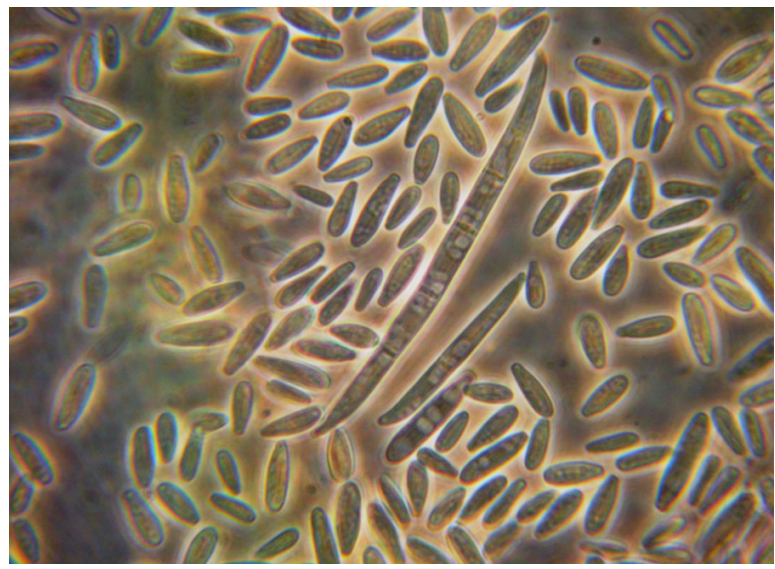

Figure 2. Fusarium microconidia and macroconidia.

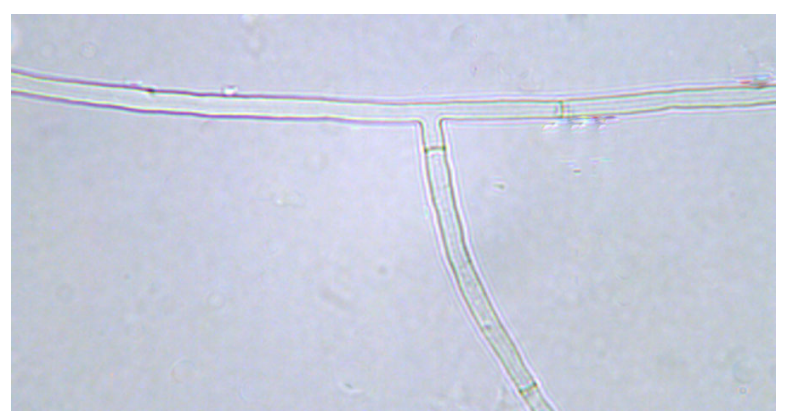

Figure 3. Rhizoctonia hyphae.

Wind often disperses many fungal pathogens. Spores can be carried for miles by wind. Splashing water, from rainfall or irrigation, will also move fungal spores from plant to plant. Fungi that live in the soil can move from plant to plant by growing along intermingled roots or out from infested plant debris in the soil. Some fungi (e.g., Rhizoctonia) can survive on their own for long periods of time without a host by living in plant debris or soil. Fungi can also be spread by human activity, through movement of already diseased plants or the use of gardening tools. While fungi may enter a plant through its natural openings (e.g., stomates), or through wounds, they can also penetrate directly through the plant's cuticle as well.

\section{Bacteria}

Bacteria are one-celled microorganisms that are so small they can be seen only with a powerful light microscope (Fig. 4). Most plant pathogenic bacteria do not produce spores. Although some bacteria can survive in the soil in decaying plant material for a time, they usually need a host to survive.

Bacteria are dependent on outside agents for dispersal from plant to plant. Splashing water (irrigation, wind-driven rain) is the chief means by which bacteria are disseminated (Fig. 5). Another important means of dispersal is through human contact. Many bacterial diseases can be spread simply through the process of touching an infected plant and then touching a healthy plant with hands or pruning tools. Bacteria cannot penetrate the cuticle of plants, but must enter the plant through a wound or natural opening to initiate disease. A special sub-group of bacteria called phytoplasmas require an insect host for dispersal and entry into the plant.

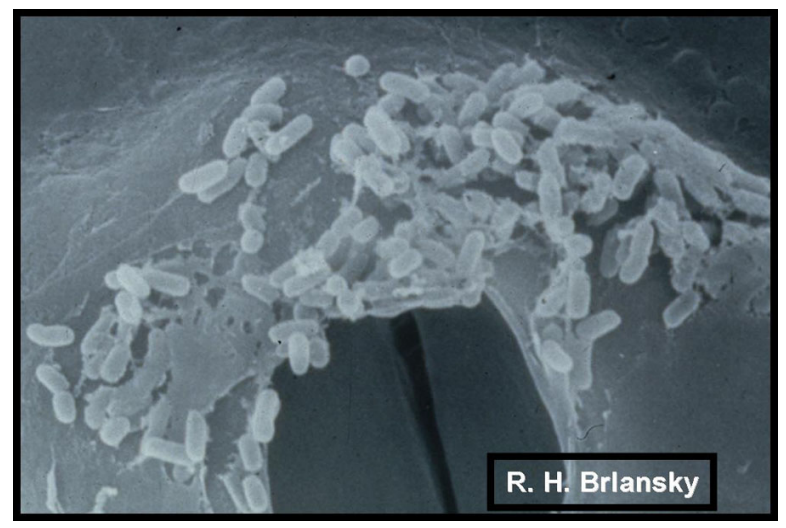

Figure 4. Bacterial cells viewed with electron microscope.

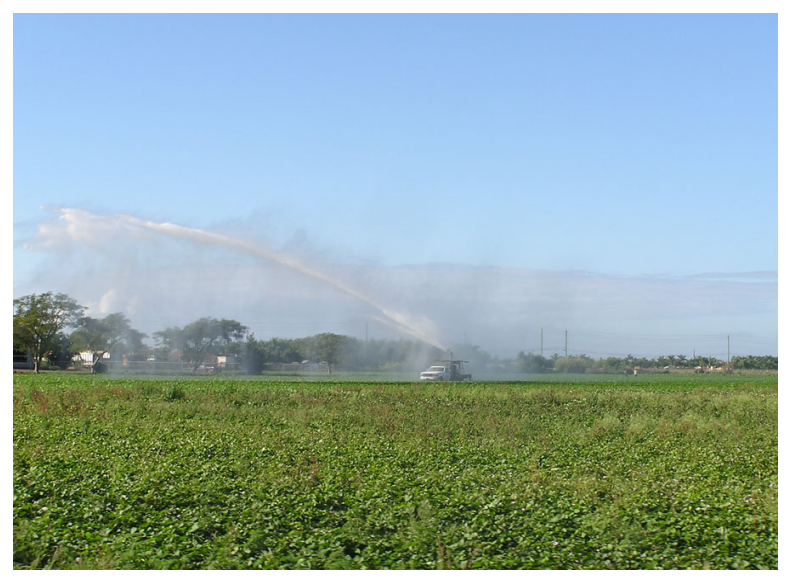

Figure 5. Overhead irrigation exacerbates bacterial diseases. 


\section{Viruses}

Viruses are the smallest of the three pathogens described here, and can only be seen with an electron microscope (Fig. 6). They are made up of genetic material (RNA or DNA), which is usually wrapped in a protein coat. They must have a living host in order to reproduce, because they use plant host cells in the reproduction process. Most fungi and bacteria reproduce independent of the plant host. Viruses are usually spread from diseased to healthy plants by insects, but can also be spread by mites, nematodes, fungi and even humans. The organism spreading the virus is referred to as a vector. In Florida, most viruses are vectored by insects, primarily aphids or whiteflies.

Please note that all of the previously described plant pathogens (even some viruses) can be spread on contaminated tools and equipment. Therefore, it is very important to follow the management recommendations outlined in Guidelines for Identification and Management of Plant Disease: Part III. Managing Plant Diseases (http://edis.ifas.ufl.edu/MG443).

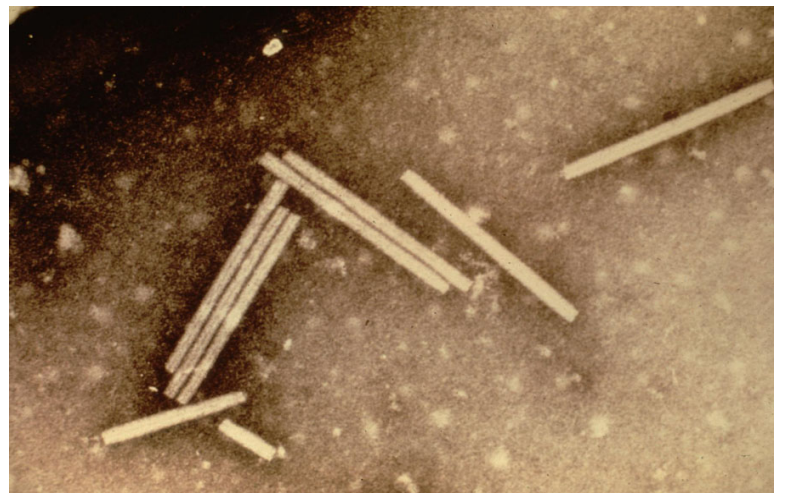

Figure 6. Virus particles of tobacco mosaic virus.

\section{Symptoms and Signs}

\section{Symptoms}

Symptoms are abnormal features of the plant that indicate something is wrong. It is important to learn the proper name for a symptom. Many are self-explanatory. A spot is just that, a spot. It is also necessary to mention the part of the plant exhibiting the symptom. If there are spots on the leaves, they will be called leaf spots (Fig. 7); spots on the fruit are fruit spots (Fig. 8). The technical term for a spot is "lesion," which means a localized diseased area or wound. As spots grow together (coalesce), the symptom is called a blight (Fig. 9). This differs from a spot because larger amounts of tissue are affected.

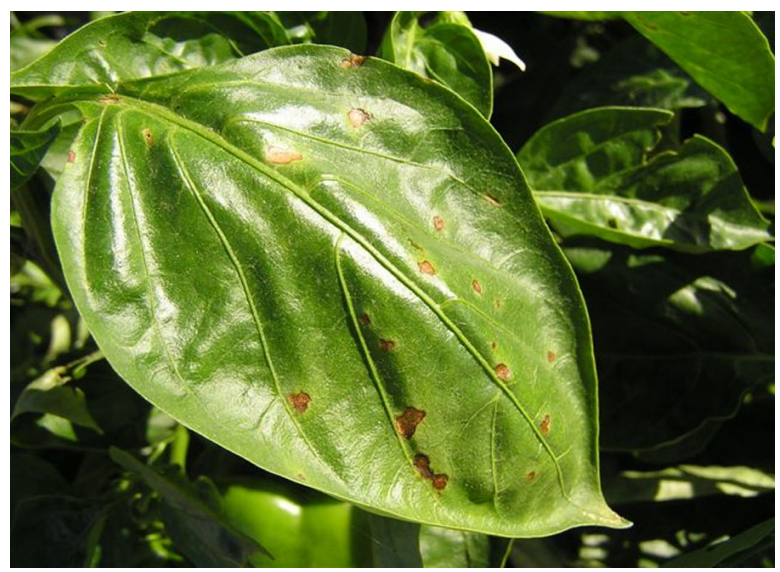

Figure 7. Leaf spots associated with bacterial spot disease.

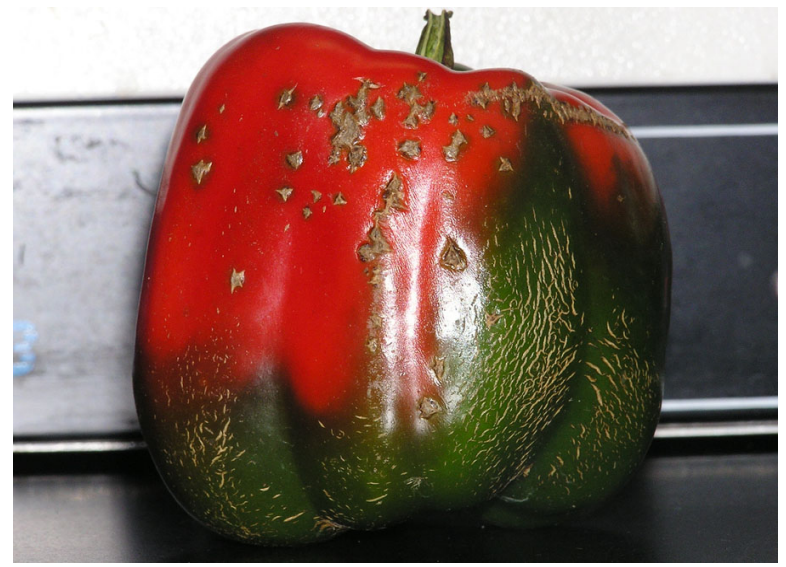

Figure 8. Fruit spots due to bacterial spot disease.

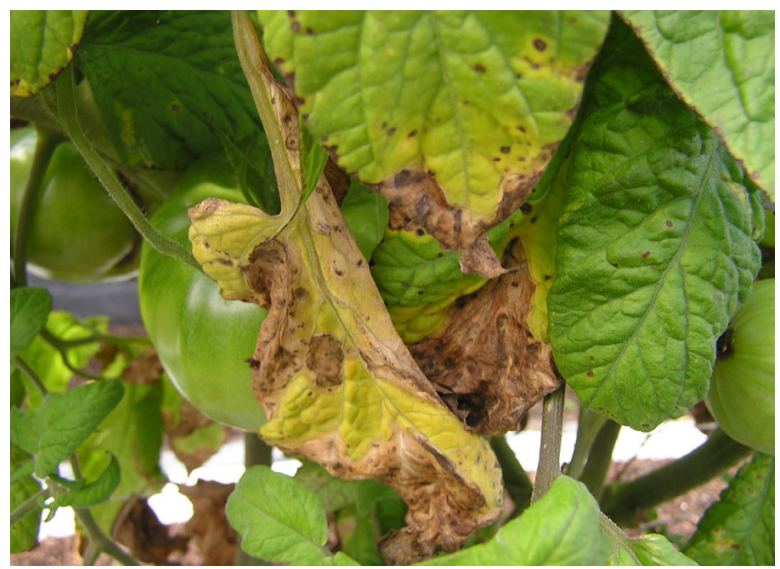

Figure 9. Leaf blight damage on tomato leaves.

Galls, or tumors, may be found on stems, roots, or sometimes on leaves (Fig. 10). These are masses of 
undifferentiated tissue growth, similar to cancerous tumors in people. They can be easily confused with those caused by insects. Cankers are sunken lesions, which are found most often on stems but can also occur on tree trunks (Fig. 11).

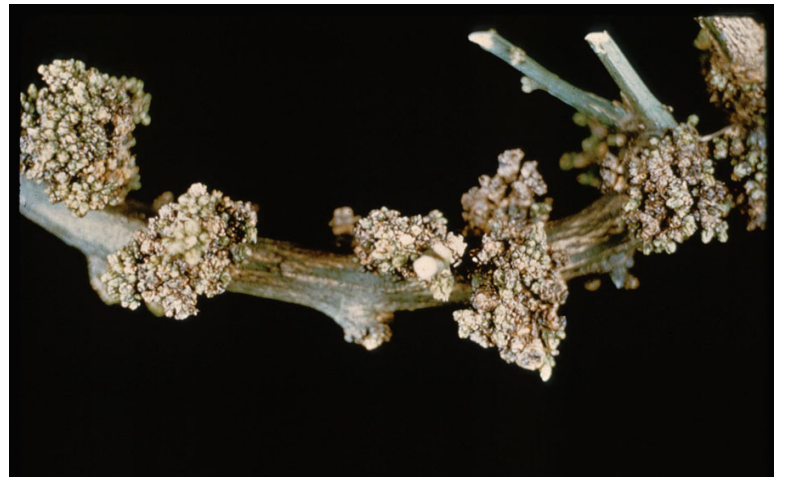

Figure 10. Galls or tumors on branch of oleander.

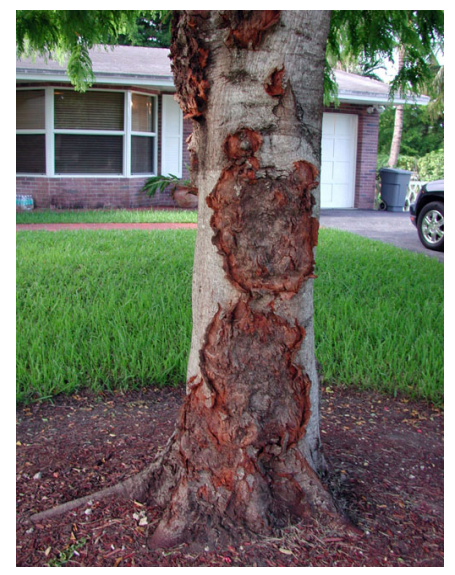

Figure 11. Trunk canker.

Wilts and rots are just what the names imply. It is important to note that a rot does not have to be wet and "yucky"; there are dry rots. A rot simply means the plant tissue is being degraded by the pathogen (Fig. 12). To tell if a pathogen is responsible for a wilt, make a vertical cut (cross-section) near the base of the plant or individual wilted stem. If a pathogen is present, the vascular (water-conducting) tissue will appear dark (Fig. 13). A plant wilting from water stress will have normal white, off-white or light-green vascular tissue.

Damping-off is a term used to describe the rotting of seedlings as they emerge from the soil or potting mix. There are two types of damping-off diseases. Pre-emergence damping-off occurs when a

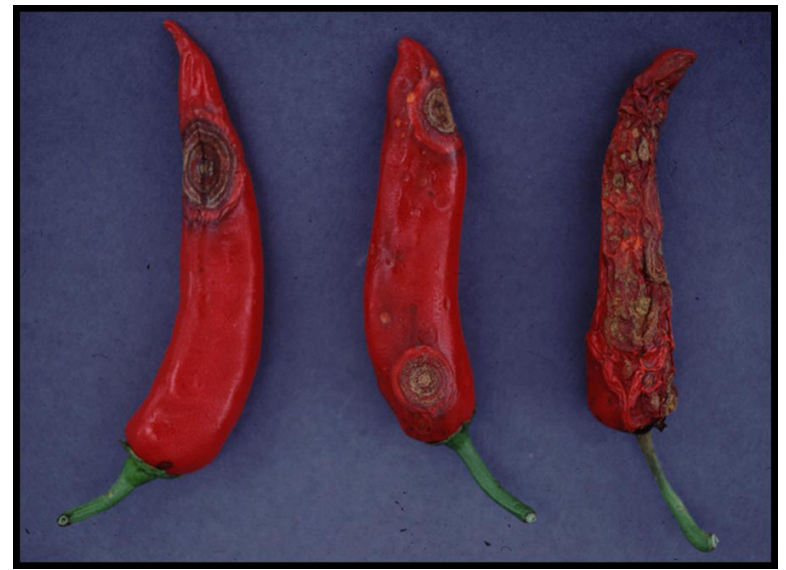

Figure 12. Fruit rot.

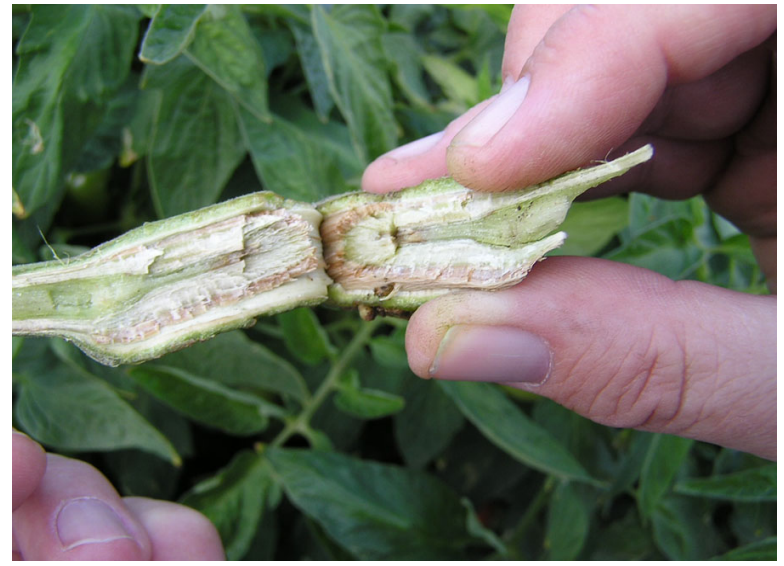

Figure 13. Vascular browning associated with a wilt disease.

germinating seed is infected and dies before it emerges from the ground. Post-emergence damping-off occurs when a fully emerged seedling is infected at the soil line and dies (Fig. 14).

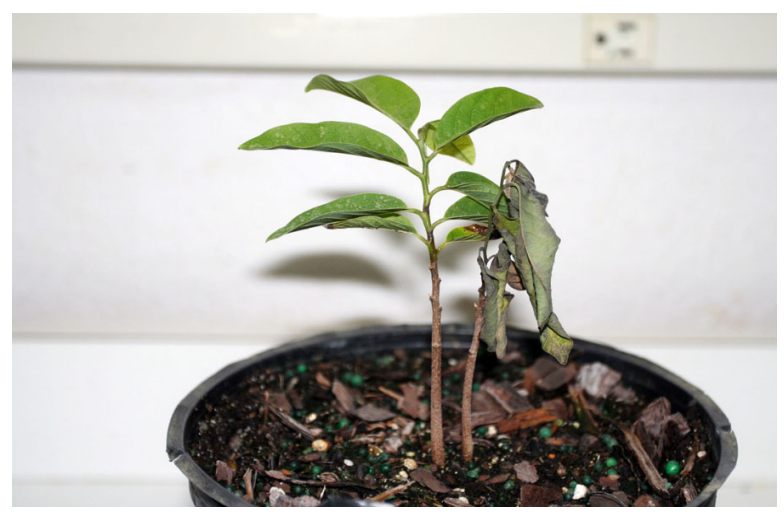

Figure 14. Post-emergence damping-off.

Terms also used to describe turfgrass diseases include patch and decline. These terms are describing 
areas (small or large) of affected turf and not individual plants (Fig. 15). The individual plants in the patch or decline area will exhibit symptoms of spots, blights, rots or wilts (Fig. 16).

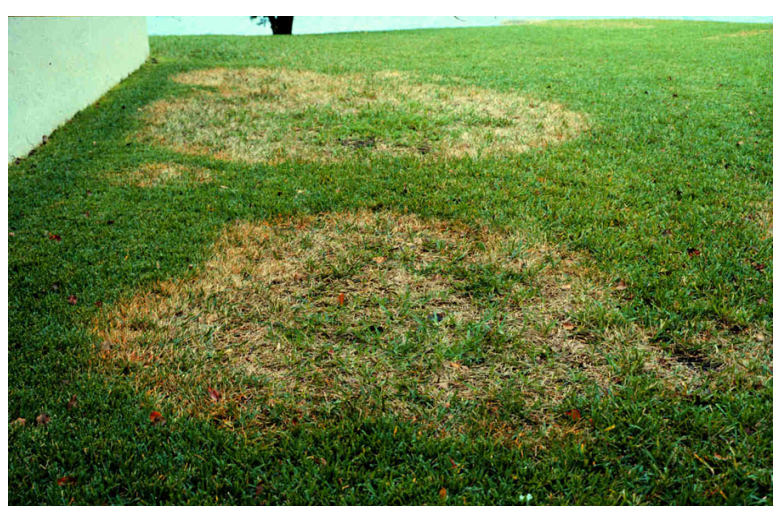

Figure 15. Brown patch.

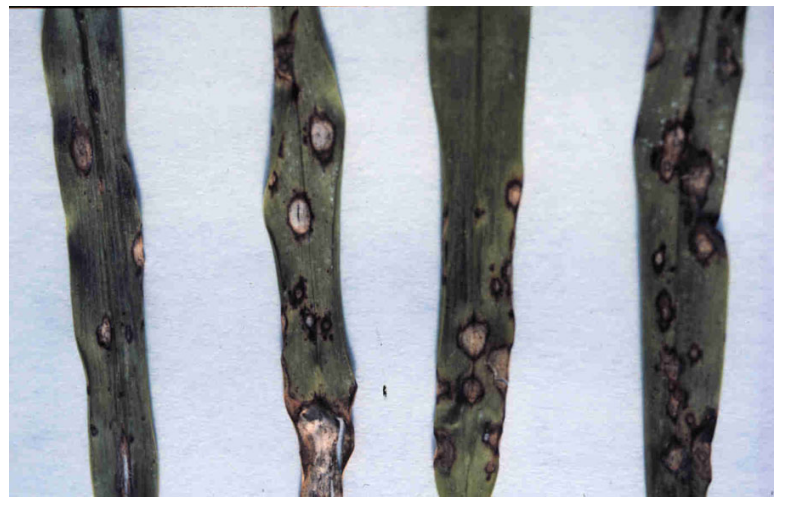

Figure 16. Gray leaf spot.

Most of the symptoms described above are normally associated with fungal or bacterial pathogens. Symptoms of viral diseases include mottling in the color of leaves and fruit (mosaics) (Fig. 17), yellowing and/or crinkling of leaves, misshapen leaves (Fig. 18), yellow or necrotic rings on leaves or fruits, and plants that appear dwarfed because they have shortened internodes (Fig. 19).

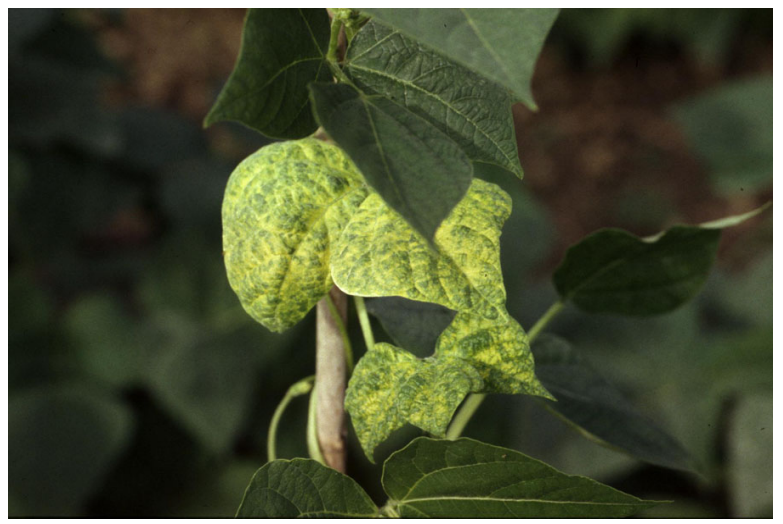

Figure 17. Bright yellow mosaic due to virus infection.

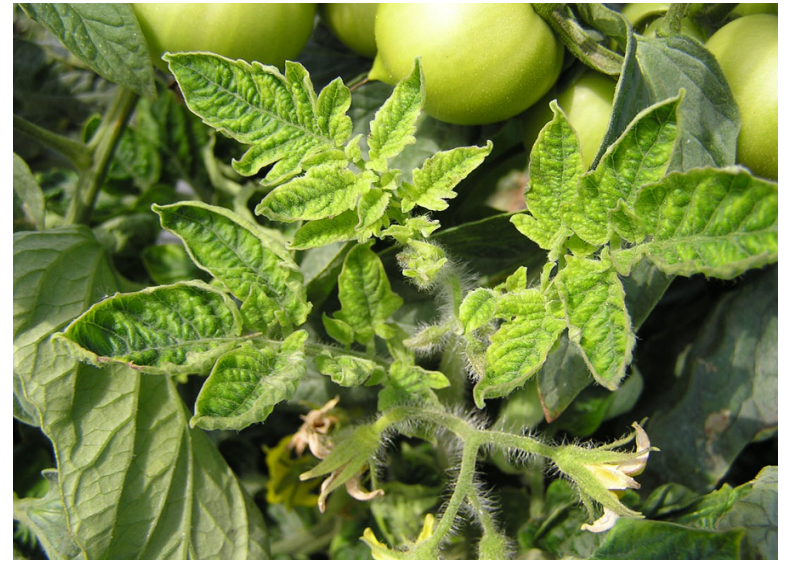

Figure 18. Yellow crinkled leaves of viral-infected tomato.

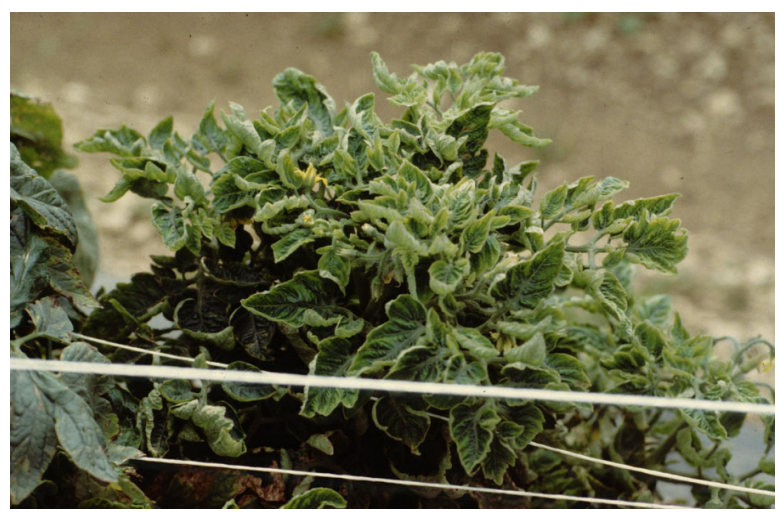

Figure 19. Stunted tomato plant due to viral infection.

\section{Signs}

A positive diagnosis of a plant disease is often difficult or nearly impossible to make on the basis of symptoms alone. Too often, symptoms of specific diseases and some abiotic disorders overlap. To properly identify a fungal or bacterial disease, one must look for the signs of the pathogen, the most significant of which is the presence of the pathogen itself viewed with the unaided eye, a hand lens or a microscope.

With fungal diseases, one can often see the actual fungal growth. Examples of these signs are mycelium, spore masses such as molds or rusts, sclerotia, conks and mushrooms (Fig. 20). A mycelium is a mass of fungal "threads" that can often be seen on or around a lesion (spot, canker, blighted area). Sclerotia are small, hard bodies which are the resting state of some fungi (Fig. 21). Fungi can survive for years in this state. They are most often found inside plant tissue, such as stems. 


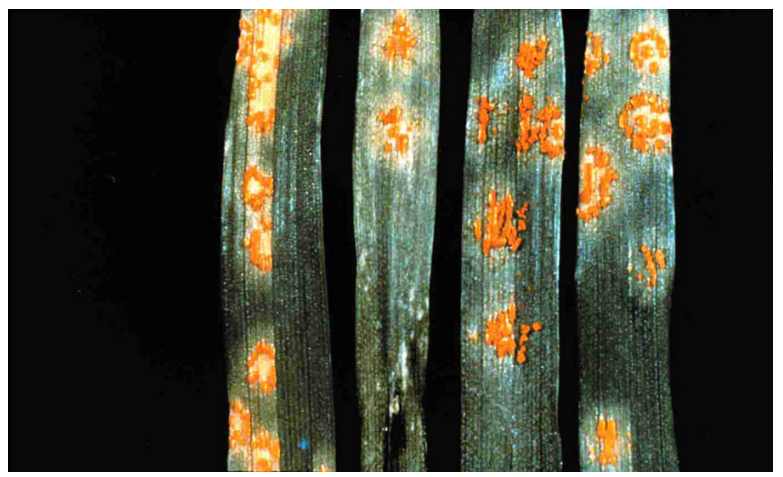

Figure 20. Leaf rust.

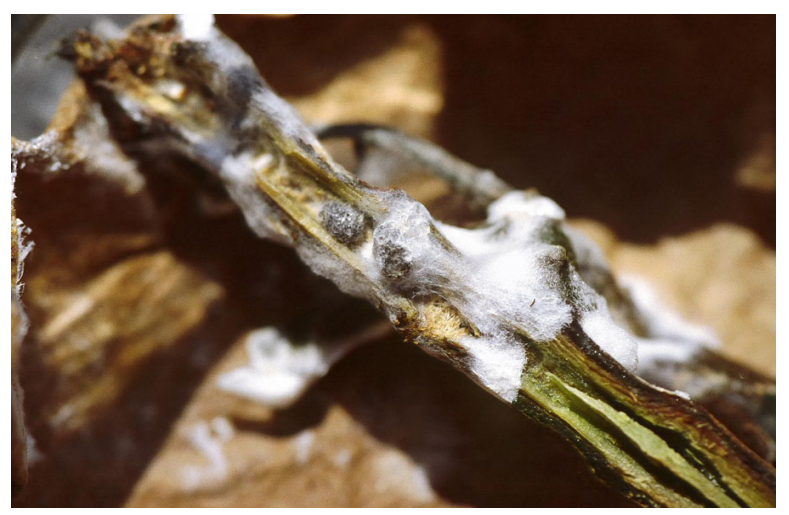

Figure 21. Fungal growth and sclerotia.

If a fungus is suspected as the cause of a disease, but there is no sign of the fungus, a moisture chamber can be made to induce fungal growth. This is a sealed container (e.g., a plastic storage container) in which a piece of the diseased tissue is placed on a moist paper towel. After a day or two in the closed container, mycelium will often be evident if the disease is indeed caused by a fungus (Fig. 22). This works best if the infection is relatively recent or the symptom is a spot, blight or canker. If the plant tissue is degraded (starting to rot), additional fungi are likely to grow from the infected tissue, making it difficult to identify the original pathogen.

Along with the symptoms described above, bacterial infections often produce water-soaking around the area where the pathogen entered (Fig. 23). Later, the lower surface of the leaf will take on a dark, greasy appearance. This greasy appearance is most evident in foliar infections, but can sometimes be seen on other plant organs. Although these are good indications of a bacterial disease, one must again look for signs of the pathogen. Often, bacterial ooze can be seen coming from a lesion, especially in the

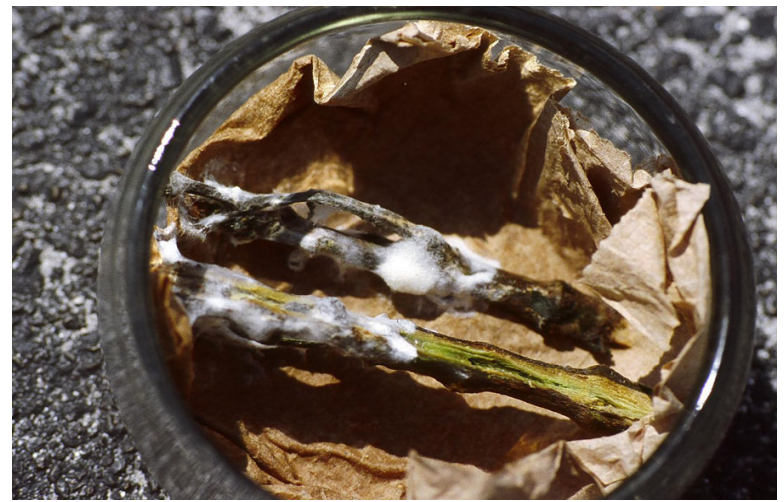

Figure 22. Moisture chamber used to encourage growth of funga.

morning hours (Fig. 24). Some bacterial diseases also have distinctive odors.

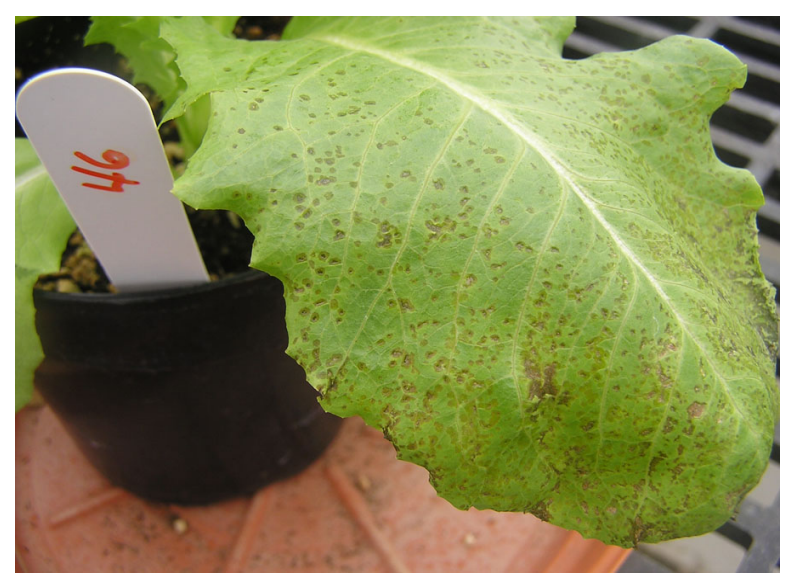

Figure 23. Watersoaked lesions due to bacteria.

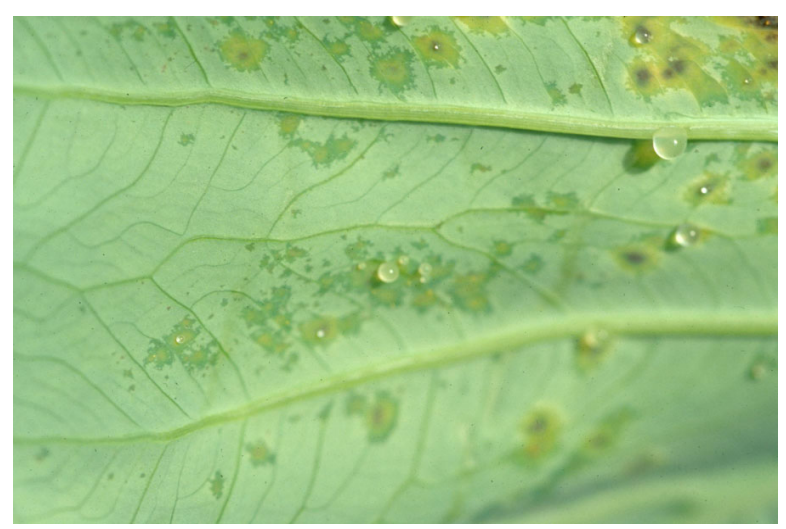

Figure 24. Droplets of bacterial ooze.

An easy test to determine whether wilt symptoms are caused by bacteria is called a bacterial streaming test. This may be done by cutting the stem horizontally and inserting the cut end into a clear glass container filled half-way with water. If bacteria are present, they will produce a cloudy stream within a few 
minutes (Fig. 25). This stream is composed of millions of bacteria.

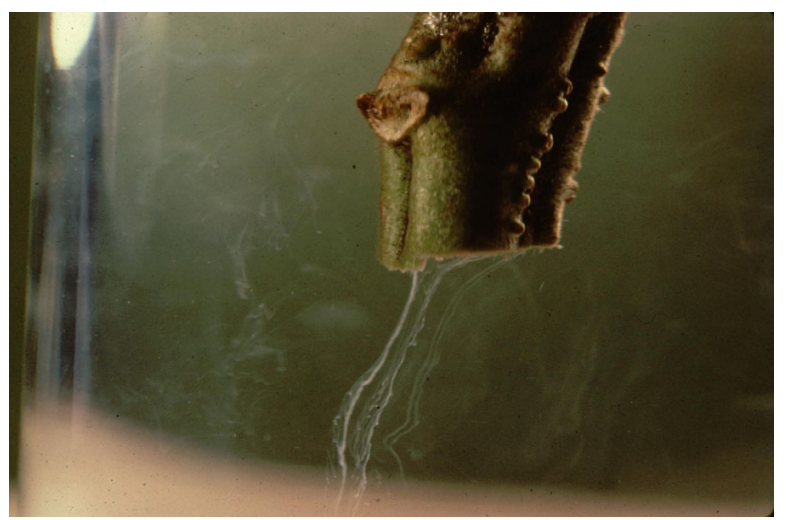

In order to obtain a definitive diagnosis of a virus, samples must be sent to a clinic that has the special equipment and materials necessary to do the proper tests.

\section{Preliminary Dignostic Equipment}

As indicated in this discussion, a few simple tools are useful for preliminary diagnosis of plant diseases. These include a hand lens, sharp knife, clear glass container or jar, plastic storage container and rubbing alcohol. A hand lens is often necessary to see the fungal growth on a lesion. The knife is used to make cross-sections of stem tissue. Clean the knife after each use with a tissue or cotton ball soaked with rubbing alcohol. The glass jar is used for the bacterial streaming test, and the storage container becomes a moisture chamber for inducing fungal growth from infected tissue.

\section{Disease Diagnostic Information and Submission of Samples}

There are several steps the Master Gardener should take when attempting to diagnose disease problems in the plants brought into the Extension office. First, it is almost impossible to make a diagnosis if the plant is dead or very close to death. A good sample will include multiple examples of the symptoms and, ideally, multiple samples illustrating how the disease progresses in the plant. Ask the plant owner for information regarding how many plants are affected, when symptoms appeared, the pattern of development in the field or garden, the severity of the disease, any recent cultural practices (e.g., use of pesticides or fertilizers), and any weather conditions that might have affected the plants. Refer to the list of questions in Part IV of this series at http://edis.ifas.ufl.edu/MG444. Handouts and other reference materials are available in the Extension office.

Additional help is available through several plant diagnostic clinics run by University of Florida plant pathologists around the state. Your Master Gardener coordinator can recommend a clinic when one is needed and also what procedures to follow in dealing with fees, proper packaging of samples, and the appropriate paperwork. EDIS publication "Florida Extension Plant Disease Clinic Network" (http://edis.ifas.ufl.edu/SR007) describes the clinics and provides information on proper sample submission.

\section{Web resources for plant diagnosis in Florida}

- EDIS home page http://edis.ifas.ufl.edu. Search using the plant name. Many general publications about a particular plant will list the more common diseases associated with that plant. While it is important to be aware of new plant diseases, most questions and samples will concern common diseases.

- Florida Extension Plant Disease Clinic Network http://edis.ifas.ufl.edu/SR007

- Florida Extension Plant Diagnostic Network http://edis.ifas.ufl.edu/PP151

- Master Gardener page on EREC Web Site http://erec.ifas.ufl.edu/MG/

- A Series on Diseases in the Florida Vegetable Garden:

Tomato http://edis.ifas.ufl.edu/PP121. Pepper http://edis.ifas.ufl.edu/PP122. Cantaloupe http://edis.ifas.ufl.edu/PP158

- Diseases in Florida Vegetable Garden Beans: Bush, Lima, Pole, Wax, Southern Peas, English Peas, and Snow Peas 
http://edis.ifas.ufl.edu/PP132

- A Guide to Citrus Disease Identification http://edis.ifas.ufl.edu/CH159

- Diseases of Avocado in Florida http://edis.ifas.ufl.edu/VH047

- Some Common Diseases of Mango in Florida http://edis.ifas.ufl.edu/VH048

- Some Common Diseases of Papaya in Florida http://edis.ifas.ufl.edu/VH050

- Key for Identification of Landscape Turfgrass Diseaseshttp://edis.ifas.ufl.edu/LH064

- A Key to Common Landscape Palm Disorders and Diseases in the Continental United States http://flrec.ifas.ufl.edu/ $\underline{\text { KeyToPalmDisordersAnd Diseases.pdf }}$ 